\title{
PENGARUH PELATIHAN KERJA, PENGEMBANGAN KARIR DAN LINGKUNGAN KERJA TERHADAP KINERJA PEGAWAI DI DINAS CIPTA KARYA KABUPATEN BANYUMAS
}

\author{
Laila Nur Ajizah \\ Fakultas Ekonomi Universitas Muhammadiyah Purwokerto \\ Suyoto \\ Fakultas Ekonomi Universitas Muhammadiyah Purwokerto \\ Hengky Widhiandono \\ Fakultas Ekonomi Universitas Muhammadiyah Purwokerto
}

\begin{abstract}
This study aimed to determine the effect of job training, career development and work environment on the performance of employees in Department of Human Settlements Banyumas regency, either partially or simultaneously. The method used in the sampling is purposive sampling, the sampling was based on the consideration to fit the study criteria in order to increase the accuracy of the sample. The analysis method used is multiple linear regression with the significant level $(\alpha) 0.05$.

The results of this study concluded that the positive effect of job training on the performance of employees in the Department of Human Settlements Banyumas regency, with a significant value of 0.031 is less than 0.05. Career development positive influence on the performance of employees in the Department of Human Settlements Banyumas regency, with a significant value of 0.000 is less than 0.05. The work environment positive influence on the performance of employees in the Department of Human Settlements Banyumas regency, with significant value of 0.000 is less than 0.05. Job training, career development and work environment simultaneously affects the performance of employees in the Department of Human Settlements Banyumas regency, with a significant value of 0.000 is less than 0.05.

Advice for leaders should work to improve the training of civil servants stationed appropriate initial education field and conducted the training as well as suggestions for training held in accordance with the needs of employees so that employees fully understand their duties and functions. To enhance the career development of employees should know the position / employee positions will get next. To improve the work environment should provide a place of their own to save the document to make it look more presentable. To improve the performance of the three points above should be met then the performance of employees will increase.
\end{abstract}

Keywords: Job Training, Career Development, Work Environment and Employee Performance 


\begin{abstract}
ABSTRAK
Penelitian ini bertujuan untuk mengetahui pengaruh pelatihan kerja, pengembangan karir dan lingkungan kerja terhadap kinerja karyawan di Dinas Cipta Karya Kabupaten Banyumas, baik secara parsial maupun simultan. Metode yang digunakan dalam pengambilan sampel adalah purposive sampling, sampling didasarkan pada pertimbangan agar sesuai dengan kriteria penelitian dalam rangka meningkatkan akurasi sampel. Metode analisis yang digunakan adalah regresi linier berganda dengan tingkat signifikan $(\alpha) 0,05$.

Hasil penelitian ini menyimpulkan bahwa dampak positif dari pelatihan kerja terhadap kinerja karyawan di Dinas Cipta Karya Kabupaten Banyumas, dengan nilai signifikan 0,031 kurang dari 0,05 . pengembangan karir berpengaruh positif terhadap kinerja karyawan di Dinas Cipta Karya Kabupaten Banyumas, dengan nilai signifikan 0,000 kurang dari 0,05. Lingkungan kerja berpengaruh positif terhadap kinerja karyawan di Dinas Cipta Karya Kabupaten Banyumas, dengan nilai signifikan 0,000 kurang dari 0,05. pelatihan kerja, pengembangan karir dan lingkungan kerja secara simultan mempengaruhi kinerja karyawan di Dinas Cipta Karya Kabupaten Banyumas, dengan nilai signifikan 0,000 kurang dari 0,05.

Saran bagi para pimpinan harus berusaha untuk meningkatkan pelatihan pegawai negeri yang ditempatkan bidang pendidikan awal yang tepat dan melakukan pelatihan, serta saran untuk pelatihan diselenggarakan sesuai dengan kebutuhan karyawan sehingga karyawan memahami tugas dan fungsinya. Untuk meningkatkan pengembangan karir karyawan harus tahu posisi / jabatan karyawan yang akan didapatkan berikutnya. Untuk meningkatkan lingkungan kerja harus menyediakan tempat bagi mereka untuk menyimpan dokumen agar terlihat lebih rapi. Untuk meningkatkan kinerja maka tiga poin di atas harus dipenuhi, maka kinerja karyawan akan meningkat.
\end{abstract}

Kata Kunci: Pelatihan Kerja, Pengembangan Karir, Lingkungan Kerja dan kinerja karyawan.

\title{
I. PENDAHULUAN
}

Manusia dalam sebuah organisasi memiliki peran yang sangat sentral dalam menggerakan roda perkembangan dan laju produktivitas perusahaan. Manusia sebagai sumber daya potensial merupakan sumber kekuatan suatu organisasi, sebab manusialah yang menggerakan organisasi. Mengingat peran yang dominan tersebut, maka segala upaya harus dilakukan untuk menciptakan sebuah sistem yang mengatur kinerja manusia agar lebih efektif dan efisien dalam organisasi. Apalagi dalam era globalisasi ini laju modernisasi dan perkembangan teknologi menuntut organisasi untuk lebih peka dan responsif terhadap tuntutan zaman.

Kinerja karyawan merupakan hasil kerja yang dicapai seseorang dalam melaksanakan tugas-tugas yang dibebankan kepadanya. Kinerja karyawan meliputi kualitas dan kuantitas output serta keandalan dalam bekerja. Karyawan dapat bekerja dengan baik bila memiliki kinerja yang tinggi sehingga dapat menghasilkan kerja yang baik pula. Dengan adanya kinerja yang tinggi yang dimiliki karyawan, diharapkan tujuan organisasi dapat tercapai. Sebaliknya, tujuan organisasi susah atau bahkan tidak dapat tercapai bila karyawannya bekerja tidak memiliki kinerja yang baik sehingga tidak dapat menghasilkan kerja yang baik pula (Lewa dan Subowo, 2005). Berdasarkan wawancara dengan pegawai Dinas Cipta Karya Kabupaten Banyumas, diperoleh keterangan bahwa kinerja pegawai Dinas Cipta Karya Kabupaten Banyumas sudah sesuai dengan tugas pokok masing-masing fungsi, dengan demikian kinerja pegawai sudah baik.

Penelitian yang dilakukan oleh Parlinda dan Wahyuddin (2004) tentang Pengaruh Kepemimpinan, Motivasi, Pelatihan, Dan Lingkungan Kerja Terhadap Kinerja Karyawan Pada Perusahaan Daerah Air Minum Kota Surakarta, menemukan bukti bahwa kepemimpinan, motivasi, pelatihan, dan lingkungan kerja secara bersama-sama berpengaruh signifikan terhadap kinerja karyawan pada dinas PDAM Surakarta. Sedangkan secara parsial hanya pelatihan kerja dan 
lingkungan kerja yang berpengaruh signifikan sedangkan kepemimpinan dan motifasi tidak berpengaruh.

Penelitian lain dilakukan oleh Burlian (2005) melakukan penelitian tentang pengaruh pengembangan karir terhadap kinerja pegawai balai karantina ikan Polonia di Medan, menemukan bukti bahwa pengembangan karir berpengaruh terhadap kinerja pegawai.

Selain Parlinda dan Wahyuddin (2004) dan Burlian (2005) terdapat penelitian lain yaitu Lewa dan Subowo (2005) melakukan penelitian tentang pengaruh kepemimpinan, lingkungan kerja fisik dan kompensasi terhadap kinerja karyawan di PT. Pertamina (persero) daerah operasi hulu Jawa bagian barat, Cirebon, menemukan bukti bahwa variabel kepemimpinan, lingkungan kerja fisik dan kompensasi mempunyai pengaruh baik secara parsial maupun simultan terhadap kinerja karyawan di PT. Pertamina (Persero) Daerah Operasi Hulu Jawa Bagian Barat, Cirebon.

Berdasarkan wawancara dengan pegawai Dinas Cipta Karya Kabupaten Banyumas, diperoleh keterangan bahwa di Dinas Cipta Karya Kabupaten Banyumas belum pernah diadakan penelitian tentang pengaruh pelatihan kerja, pengembangan karir dan lingkungan kerja terhadap kinerja karyawan, sehingga penelitian ini diharapkan dapat memberikan masukan bagi Dinas Cipta Karya Kabupaten Banyumas untuk meningkatkan kinerja karyawan. Selain hal tersebut juga berdasarkan hasil penelitian terdahulu terdapat beberapa faktor yang dapat mempengaruhi kinerja. Oleh karena itu peneliti bermaksud untuk mengadakan penelitian tentang pengaruh pelatihan kerja, pengembangan karir dan lingkungan kerja terhadap kinerja karyawan.

Salah satu variabel yang mempengaruhi kinerja karyawan adalah pelatihan kerja. Pelatihan dapat didefinisikan sebagai suatu cara yang digunakan untuk memberikan atau meningkatkan ketrampilan yang dibutuhkan untkuk melaksanakan pekerjaan sekarang (Penggabean, 2002). Pelatihan kerja penting bagi para karyawan, karena melalui pelatihan ini para karyawan bisa terbantu mengerjakan pekerjaannya, dapat pula meningkatkan prestasi kerja karyawan. Pelatihan bagi karyawan merupakan sebuah proses mengajarkan pengetahuan dan keahlian tertentu serta sikap agar karyawan semakin terampil dan mampu melaksanakan tanggung jawabnya dengan semakin baik, sesuai dengan kapasitasnya masing-masing (Parlinda dan Wahyuddin, 2004). Berdasarkan wawancara dengan pegawai Dinas Cipta Karya Kabupaten Banyumas, diperoleh keterangan bahwa di Dinas Cipta Karya Kabupaten Banyumas pelatihan kerja pegawai dilakukan secara berkala (setahun dua kali) dalam bentuk diklat dan bimbingan teknis.

Variabel penelitian berikutnya adalah pengembangan karir. Pengembangan karir (carrier development) adalah suatu kondisi yang menunjukan adanya peningkatan-peningkatan status seseorang dalam suatu organisasi dalam jalur karir yang telah ditetapkan dalam organisasi yang bersangkutan (Martoyo, 1998). Pengembangan karir di Dinas Cipta Karya Kabupaten Banyumas dilakukan dengan mengajukan usulan kepada Bupati, sedangkan untuk pengembangan karir kepala dinas diajukan kepada Gubernur. Adapun bentuk pengembangan karir berdasarkan wawancara dengan pegawai Dinas Cipta Karya Kabupaten Banyumas, antara lain kenaikan golongan, promosi jabatan, roling dengan posisi yang lebih tinggi.

Selain pelatihan kerja dan pengembangan karir, lingkungan kerja juga dapat mempengaruhi kinerja. Menurut Ahyari (dalam Lewa dan Subowo, 2005) lingkungan kerja adalah suatu lingkungan dimana karyawan bekerja, sedangkan kondisi kerja merupakan kondisi dimana karyawan tersebut bekerja. Dengan demikian sebenarnya kondisi kerja termasuk salah satu unsur lingkungan kerja.

Lingkungan kerja ini sendiri terdiri atas fisik dan nonfisik yang melekat dengan karyawan sehingga tidak dapat dipisahkan dari usaha pengembangan kinerja karyawan. Lingkungan kerja yang segar, nyaman, dan memenuhi standart kebutuhan layak akan memberikan kontribusi terhadap kenyamanan karyawan dalam melakukan tugasnya. Lingkungan kerja nonfisik yang meliputi keramahan sikap para karyawan, sikap saling menghargai diwaktu berbeda pendapat, dan lain sebagainya adalah syarat wajib untuk terus membina kualitas pemikiran karyawan yang akhirnya bisa membina kinerja mereka secara terus-menerus (Parlinda dan Wahyuddin, 2004). Berdasarkan wawancara dengan pegawai Dinas Cipta Karya Kabupaten Banyumas, diperoleh keterangan bahwa lingkungan kerja Dinas Cipta Karya Kabupaten Banyumas sudah baik dengan fasilitas yang cukup lengkap. 
Penelitian ini merupakan replikasi dari penelitian Parlinda dan Wahyuddin (2004), adapun perbedaan penelitian ini dengan penelitian sebelumnya terletak pada penggunaan variabel dan objek penelitian. Penelitian terdahulu menggunakan variabel kepemimpinan, motivasi, pelatihan, lingkungan kerja dan kinerja karyawan dengan objek Perusahaan Daerah Air Minum Kota Surakarta, sedangkan penelitian ini menggunakan variabel pelatihan kerja, pengembangan karir, lingkungan kerja dan kinerja karyawan, dengan objek penelitian Dinas Cipta Karya Kabupaten Banyumas. Berdasarkan latar belakang tersebut maka peneliti ingin mengadakan penelitian dengan judul "pengaruh pelatihan kerja, pengembangan karir dan lingkungan kerja terhadap kinerja pegawai di Dinas Cipta Karya Kabupaten Banyumas".

\section{Tujuan Penelitian}

1. Apakah pelatihan kerja berpengaruh positif terhadap kinerja pegawai di Dinas Cipta Karya Kabupaten Banyumas.

2. Apakah pengembangan karir berpengaruh positif terhadap kinerja pegawai di Dinas Cipta Karya Kabupaten Banyumas.

3. Apakah lingkungan kerja berpengaruh positif terhadap kinerja pegawai di Dinas Cipta Karya Kabupaten Banyumas.

4. Apakah pelatihan kerja, pengembangan karir dan lingkungan kerja secara simultan berpengaruh terhadap kinerja pegawai di Dinas Cipta Karya Kabupaten Banyumas. berikut:

Berdasarkan uraian diatas maka hipotesis dalam penelitian ini dapat dirumuskan sebagai

$\mathrm{H}_{1}=$ Pelatihan kerja berpengaruh positif terhadap kinerja pegawai di Dinas Cipta Karya Kabupaten Banyumas.

$\mathrm{H}_{2}=$ Pengembangan karir berpengaruh positif terhadap kinerja pegawai di Dinas Cipta Karya Kabupaten Banyumas.

$\mathrm{H}_{3}=$ Lingkungan kerja berpengaruh positif terhadap kinerja pegawai di Dinas Cipta Karya Kabupaten Banyumas.

$\mathrm{H}_{4}=$ Pelatihan kerja, pengembangan karir dan lingkungan kerja secara simultan berpengaruh terhadap kinerja pegawai di Dinas Cipta Karya Kabupaten Banyumas.

\section{Metodologi Penelitian}

\section{Populasi dan Sampel}

Populasi adalah keseluruhan dari subjek-subjek yang karakteristiknya akan diduga. Populasi dalam penelitian ini adalah seluruh pegawai Dinas Cipta Karya Kabupaten Banyumas yang berjumlah 496 orang. Sampel dalam penelitian ini diambil dengan menggunakan metode purposive sampling, yaitu pengambilan sampel yang didasarkan pada pertimbangan untuk menyesuaikan dengan kriteria penelitian agar dapat meningkatkan ketepatan sampel (Sugiyono, 2004). Dengan kriteria:

1. Pegawai tetap (PNS)

2. Masa kerja minimal 5 tahun

3. Pendidikan minimal SLTA

4. Pegawai yang telah mengikuti pelatihan kerja

\section{Definisi Operasional}

1. Pelatihan Karyawan

Pelatihan (training) merupakan proses pebelajaran yang melibatkan perolehan keahlian, konsep, peraturan, atau sikap untuk meningkatkan kinerja karyawan (Simamora, 2004). Indikator variabel pelatihan karyawan terdiri dari (Barthos, 2004):

1. Latihan kerja harus sesuai dengan kebutuhan pasar kerja dan kesempatan kerja.

2. Latihan kerja harus senantiasa muktahir sesuai dengan perkembangan ilmu pengetahuan dan teknologi. 
3. Latihan kerja merupakan kegiatan yang bersifat terpadu dalam arti proses kaitan dengan pendidikan, latihan dan perkembangan satu dengan yang lain.

2. Pengembangan Karir

Martoyo (1998), mengatakan bahwa pengembangan karir (carrier development) adalah suatu kondisi yang menunjukan adanya peningkatan-peningkatan status seseorang dalam suatu organisasi dalam jalur karir yang telah ditetapkan dalam organisasi yang bersangkutan. Indikator pengembangan karir yang akan diteliti meliputi (Gomes, 1997):

1. Adanya perencanaan karir

2. Adanya manajemen karir

3 .

3. Lingkungan Kerja

Menurut Nitisemito (1996) lingkungan kerja adalah "segala sesuatu yang ada di sekitar para pekerja dan dapat mempengaruhi dirinya dalam menjalankan tugas yang di bebankan. Indikator-indikator lingkungan kerja menurut Sedarmayanti (2001) adalah sebagai berikut :

1. Penerangan yang baik

2. Pengaturan suhu udara yang baik

3. Pengendalian suara bising

4. Penggunaan warna yang sesuai

5. Ruang gerak yang diperlukan

6. Keamanan kerja yang terjamin

7. Hubungan karyawan yang baik

4. Kinerja Karyawan

Kinerja (prestasi kerja) adalah suatu hasil kerja yang dicapai seseorang dalam melaksanakan tugas-tugas yang dibebankan kepadanya yang didasarkan atas kecakapan, pengalaman dan kesungguhan serta waktu (Hasibuan, 2000). Indikator-indikator kinerja menurut Prawirosentono (1999) dari hal ini mencakup:
1. Tepat waktu
2. Daya kreatifitas,
3. Inovasi
4. Inisiatif
5. Pedoman kerja
6. prosedur kerja
7. Target kerja

\section{Alat analisis yang digunakan.}

a. Analisis Regresi Linier Berganda

Pengujain hipotesis dalam penelitain ini menggunakan regresi linier berganda dimaksudkan untuk menguji pengaruh pelatihan kerja, pengembangan karir dan lingkungan kerja terhadap kinerja pegawai di Dinas Cipta Karya Kabupaten Banyumas. Adapun bentuk persamaan regresinya adalah sebagai berikut (Supranto, 2000):

$$
\begin{aligned}
& \mathrm{Y}=\mathrm{a}+\mathrm{b}_{1} \mathrm{X}_{1}+\mathrm{b}_{2} \mathrm{X}_{2}+\mathrm{b}_{3} \mathrm{X}_{3}+\mathrm{e} \\
& \text { Dimana : } \\
& \mathrm{Y}=\text { Kinerja pegawai } \\
& \mathrm{a}=\text { Konstanta } \\
& \mathrm{b}_{1}=\text { Koefisien regresi } \mathrm{x}_{1} \\
& \mathrm{~b}_{2}=\text { Koefisien regresi } \mathrm{x}_{2} \\
& \mathrm{~b}_{3}=\text { Koefisien regresi } \mathrm{x}_{3} \\
& \mathrm{X}_{1}=\text { Pelatihan Karyawan } \\
& \mathrm{X}_{2}=\text { Pengembangan Karir }
\end{aligned}
$$




$$
\begin{aligned}
& \mathrm{X}_{3}=\text { Lingkungan Kerja } \\
& \mathrm{e}=\text { Faktor kesalahan }
\end{aligned}
$$

\section{HASIL DAN PEMBAHASAN}

\section{Pengujian Hipotesis dan Pembahasan}

Hasil penelitian ini menunjukkan bahwa pengujian validitas dan reliabilitas serta uji asumsi klasik model regresi sudah terbebas dari permasalahan normalitas, multikolinearitas dan heteroskedastisitas. Dengan demikian model regresi sudah tepat digunakan dalam pengujian hipotesis dalam penelitian ini.

Tabel 1. Hasil Olah Data Regresi Berganda

\begin{tabular}{|c|c|c|c|c|c|}
\hline \multirow[b]{2}{*}{ Model } & \multicolumn{2}{|c|}{$\begin{array}{l}\text { Unstandardized } \\
\text { Coefficients }\end{array}$} & \multirow{2}{*}{$\begin{array}{c}\text { Standardized } \\
\text { Coefficients } \\
\text { Beta } \\
\end{array}$} & \multirow[b]{2}{*}{$\mathrm{t}$} & \multirow[b]{2}{*}{ Sig. } \\
\hline & $\mathrm{B}$ & Std. Error & & & \\
\hline $1 \quad$ (Constant) & .835 & .345 & & 2.418 & .018 \\
\hline Pelatihan Kerja & .117 & .053 & .169 & 2.192 & .031 \\
\hline Pengembangan Karir & .340 & .060 & .478 & 5.629 & .000 \\
\hline Lingkungan Kerja & .320 & .081 & .335 & 3.930 & \\
\hline
\end{tabular}
Coefficients $^{a}$

a. Dependent Variable: Kinerja

Berdasarkan tabel tersebut dapat disusun persamaan regresi sebagai beriku:

$$
\mathrm{Y}=0,835+0,117 \mathrm{X}_{1}+0,340 \mathrm{X}_{2}+0,320 \mathrm{X}_{3}
$$

\footnotetext{
Adapun interpretasi dari persamaan regresi tersebut adalah:

$\alpha=0,835$ artinya kinerja pegawai akan sebesar 0,835 satuan jika pelatihan kerja, pengembangan karir dan lingkungan kerja bernilai nol.

$\beta_{1}=0,117 \quad$ artinya kinerja pegawai akan meningkat sebesar 0,117 satuan apabila pelatihan kerja naik satu satuan dengan asumsi pengembangan karir dan lingkungan kerja bernilai tetap.

$\beta_{2}=0,340$ artinya kinerja pegawai akan meningkat sebesar 0,340 satuan apabila pengembangan karir naik satu satuan dengan asumsi pelatihan kerja dan lingkungan kerja bernilai tetap.

$\beta_{3}=0,320$ artinya kinerja pegawai akan meningkat sebesar 0,320 satuan apabila lingkungan kerja naik satu satuan dengan asumsi pelatihan kerja, pengembangan karir bernilai tetap.
}

\section{Pengujian Hipotesis}

\section{Hipotesis Pertama}

Untuk menguji pengaruh pelatihan kerja terhadap kinerja pegawai di Dinas Cipta Karya Kabupaten Banyumas, menggunakan uji t. Hasil uji t dapat dilihat dalam Tabel 1. Berdasarkan tabel tersebut diketahui bahwa variabel pelatihan kerja memiliki nilai $\mathrm{t}_{\text {hitung }}$ sebesar 2,192 sedangkan nilai $t_{\text {tabel }}$ sebesar 1,6641 dengan demikian $t_{\text {hitung }}>t_{\text {tabel }}$ yaitu 2,192 $>1,6641$ serta nilai signifikan sebesar 0,031 kurang dari 0,05 . Hal ini berarti pelatihan kerja berpengaruh positif terhadap kinerja pegawai di Dinas Cipta Karya Kabupaten Banyumas, dengan demikian hipotesis pertama diterima. 


\section{Hipotesis Kedua}

Variabel pengembangan karir memiliki nilai $t_{\text {hitung }}$ sebesar 5,629 sedangkan nilai $t_{\text {tabel }}$ sebesar 1,6641 dengan demikian $t_{\text {hitung }}>t_{\text {tabel }}$ yaitu 5,629 >1,6641 serta nilai signifikan sebesar 0,000 kurang dari 0,05 . Hal ini berarti pengembangan karir berpengaruh positif terhadap kinerja pegawai di Dinas Cipta Karya Kabupaten Banyumas, dengan demikian hipotesis kedua diterima.

\section{Hipotesis Ketiga}

Variabel lingkungan kerja memiliki nilai $t_{\text {hitung }}$ sebesar 3,930 sedangkan nilai tabel sebesar 1,6641 dengan demikian $t_{\text {hitung }}>t_{\text {tabel }}$ yaitu 3,930 >1,6641 serta nilai signifikan sebesar 0,000 kurang dari 0,05 . Hal ini berarti lingkungan kerja berpengaruh positif terhadap kinerja pegawai di Dinas Cipta Karya Kabupaten Banyumas, dengan demikian hipotesis ketiga diterima.

\section{Hipotesis Keempat}

Untuk menguji pengaruh pelatihan kerja, pengembangan karir dan lingkungan kerja secara simultan terhadap kinerja pegawai di Dinas Cipta Karya Kabupaten Banyumas, menggunakan uji F. Hasil uji F dapat dilihat dalam Tabel 2.

Tabel 2 Hasil Uji F

\begin{tabular}{|l|r|r|r|c|c|}
\hline Model & \multicolumn{1}{|c|}{$\begin{array}{c}\text { Sum of } \\
\text { Squares }\end{array}$} & df & Mean Square & F & Sig. \\
\hline $1 \quad$ Regression & 7.841 & 3 & 2.614 & 29.673 & $.000^{a}$ \\
Residual & 7.135 & 81 & .088 & & \\
Total & 14.976 & 84 & & & \\
\hline
\end{tabular}
a. Predictors: (Constant), Lingkungan Kerja, Pelatihan Kerja,
Pengembangan Karir
b. Dependent Variable: Kinerja

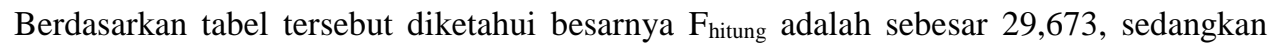
nilai $F_{\text {tabel }}$ sebesar 2,72. Sehingga diketahui $F_{\text {hitung }}>F_{\text {tabel, }}$ yaitu 29,673 $>$ 2,72 serta dengan nilai signifikan sebesar 0,000 kurang dari 0,05. Dengan demikian pelatihan kerja, pengembangan karir dan lingkungan kerja secara simultan berpengaruh terhadap kinerja pegawai di Dinas Cipta Karya Kabupaten Banyumas, sehingga hipotesis keempat diterima.

Untuk mengetahui seberapa besar pengaruh pelatihan kerja, pengembangan karir dan lingkungan kerja secara simultan berpengaruh terhadap kinerja pegawai di Dinas Cipta Karya Kabupaten Banyumas dapat dilihat melalui nilai adjusted $\mathrm{R}^{2}$, hasil uji $\mathrm{R}^{2}$ dapat dilihat dalam tabel sebagai berikut:

Tabel 3. Hasil Uji Adjusted $\mathbf{R}^{2}$

Model Summary

\begin{tabular}{|l|r|r|r|r|}
\hline Model & $\mathrm{R}$ & R Square & \multicolumn{1}{c|}{$\begin{array}{c}\text { Adjusted R } \\
\text { Square }\end{array}$} & $\begin{array}{c}\text { Std. Error of } \\
\text { the Estimate }\end{array}$ \\
\hline 1 & $.724^{\mathrm{a}}$ & .524 & .506 & .297 \\
\hline
\end{tabular}

a. Predictors: (Constant), Lingkungan Kerja, Pelatihan Kerja, Pengembangan Karir

Berdasarkan tabel tersebut diketahui nilai adjusted $\mathrm{R}^{2}$ sebesar 0,506, hal ini berarti variabel pelatihan kerja, pengembangan karir dan lingkungan kerja mempengaruhi kinerja pegawai sebesar 50,6\%, sedangkan sisanya sebesar 49,4\% dipengaruhi oleh faktor lain yang tidak diteliti misalnya kepemimpinan dan motivasi Parlinda dan Wahyuddin (2004). 


\section{Pembahasan}

Penelitian ini bertujuan untuk mengetahui pengaruh pelatihan kerja, pengembangan karir dan lingkungan kerja terhadap kinerja pegawai di Dinas Cipta Karya Kabupaten Banyumas baik secara simultan maupun parsial. Hasil penelitian ini menunjukkan bahwa pengujian asumsi klasik model regresi sudah terbebas dari permasalahan normalitas, multikolinearitas dan heteroskedastisitas sehingga model regresi sudah tepat digunakan dalam pengujian hipotesis dalam penelitian ini.

Pelatihan kerja berpengaruh positif terhadap kinerja pegawai di Dinas Cipta Karya Kabupaten Banyumas. Hal ini karena peliatihan kerja yang dilakukan akan menambah kamampuan pegawai dalam menjalankan pekerjaan mereka sehingga dapat meningkatkan kinerja mereka. Berdasarkan nilai rata pelatihan kerja tertinggi dengan nilai 3.88 yaitu pertanyaan mengenai pelatihan yang saya ikuti telah sesuai dengan kebutuhan pekerjaan saya, berdasarkan data tersebut maka pelatihan yang harus diadakan di Dinas Cipta Karya Kabupaten Banyumas harus sesuai dengan pekerjaan masing-masing pegawai. Nilai rata-rata terendah yaitu sebesar 3.44 pertanyaan tentang secara umum program pelatihan telah dilaksanakan dengan berhasil, berdasarkan data tersebut sebaiknya pelatihan yang diadakan harus sesuai dengan kebuthan pekerjaan pegawai sehingga dapat diaplikasikan dalam dunia kerja sehari-hari dengan demikian pelatihan yang dilaksanakan dapat dinilai berhasil.

Pelatihan (training) merupakan proses pebelajaran yang melibatkan perolehan keahlian, konsep, peraturan, atau sikap untuk meningkatkan kinerja karyawan (Simamora, 2004). Penelitian ini sejalan dengan penelitian Parlinda dan Wahyuddin (2004) tentang Pengaruh Kepemimpinan, Motivasi, Pelatihan, Dan Lingkungan Kerja Terhadap Kinerja Karyawan Pada Perusahaan Daerah Air Minum Kota Surakarta, menemukan bukti bahwa secara parsial hanya pelatihan kerja yang berpengaruh signifikan sedangkan kepemimpinan.

Pengembangan karir berpengaruh positif terhadap kinerja pegawai di Dinas Cipta Karya Kabupaten Banyumas. Hal ini karena kesempatan karir yang pasti akan membuat karyawan bekerja lebih baik untuk mendapatkan karir yang lebih tinggi sehingga akan meningkatkan kinerja pegawai. Berdasarkan nilai rata pengembangan karir tertinggi dengan nilai 3.67 yaitu pertanyaan mengenai setiap kenaikan jabatan telah diisi oleh pegawai yang sesuai dengan kompetensinya, berdasarkan data tersebut maka pengembangan karir di Dinas Cipta Karya Kabupaten Banyumas telah sesuai dengan kompetensi pegawai. Nilai rata-rata terendah yaitu sebesar 3.25 pertanyaan tentang pegawai telah mendapatkan penjelasan yang cukup mengenai posisi atau jabatan yang akan pegawai tempati dimasa mendatang, berdasarkan data tersebut sebaiknya pegawai mendapatkan penjelasan yang cukup mengenai posisi atau jabatan pegawai oleh atasan.

Martoyo (1998), mengatakan bahwa pengembangan karir (carrier development) adalah suatu kondisi yang menunjukan adanya peningkatan-peningkatan status seseorang dalam suatu organisasi dalam jalur karir yang telah ditetapkan dalam organisasi yang bersangkutan.

Penelitian ini sejalan dengan penelitian Burlian (2005) melakukan penelitian tentang pengaruh pengembangan karir terhadap kinerja pegawai balai karantina ikan Polonia di Medan, menemukan bukti bahwa pengembangan karir berpengaruh terhadap kinerja pegawai.

Lingkungan kerja berpengaruh positif terhadap kinerja pegawai di Dinas Cipta Karya Kabupaten Banyumas. Hal ini karena lingkungan kerja yang nyaman dengan fasilitas yang memadai akan membuat pegawai lebih mudah menyelesaikan pekerjaan sehingga kinerja mereka akan meningkat. Berdasarkan nilai rata lingkungan kerja tertinggi dengan nilai 4.18 yaitu ruang kerja pegawai tidak membahayakan, berdasarkan data tersebut maka lingkungan kerja pegawai di Dinas Cipta Karya Kabupaten Banyumas harus aman. Nilai rata-rata terendah yaitu sebesar 3.56 pertanyaan tentang pengaturan suhu udara di ruang kerja saya telah nyaman, berdasarkan data tersebut sebaiknya ruang kerja pegawai dipasang alat pendingin agar suhu udara nyaman.

Menurut Nitisemito (1992) lingkungan kerja adalah "segala sesuatu yang ada di sekitar para pekerja dan dapat mempengaruhi dirinya dalam menjalankan tugas yang di bebankan. Penelitian ini sejalan dengan penelitian Lewa dan Subowo (2005) melakukan penelitian tentang pengaruh kepemimpinan, lingkungan kerja fisik dan kompensasi terhadap kinerja karyawan di PT. Pertamina (persero) daerah operasi hulu Jawa bagian barat, Cirebon. Menemukan bukti bahwa variabel lingkungan kerja fisik mempunyai pengaruh secara parsial terhadap kinerja karyawan di PT. Pertamina (Persero) Daerah Operasi Hulu Jawa Bagian Barat, Cirebon. 
Pelatihan kerja, pengembangan karir dan lingkungan kerja secara simultan berpengaruh terhadap kinerja pegawai di Dinas Cipta Karya Kabupaten Banyumas. Hal ini berarti model regresi yang dibentuk untuk menjelaskan fenomena kinerja telah baik.

Penelitian ini sejalan dengan penelitian Parlinda dan Wahyuddin (2004) tentang Pengaruh Kepemimpinan, Motivasi, Pelatihan, Dan Lingkungan Kerja Terhadap Kinerja Karyawan Pada Perusahaan Daerah Air Minum Kota Surakarta, menemukan bukti bahwa kepemimpinan, motivasi, pelatihan, dan lingkungan kerja secara bersama-sama berpengaruh signifikan terhadap kinerja karyawan pada dinas PDAM Surakarta.

\section{KESIMPULAN DAN SARAN}

\section{Kesimpulan}

1. Pelatihan kerja berpengaruh positif terhadap kinerja pegawai di Dinas Cipta Karya Kabupaten Banyumas. Hal ini ditunjukkan dengan nilai $t_{\text {hitung }}>t_{\text {tabel }}$ yaitu 2,192 > 1,6641 serta nilai signifikan sebesar 0,031 kurang dari 0,05.

2. Pengembangan karir berpengaruh positif terhadap kinerja pegawai di Dinas Cipta Karya Kabupaten Banyumas. Hal ini ditunjukkan dengan nilai $t_{\text {hitung }}>t_{\text {tabel }}$ yaitu 5,629>1,6641 serta nilai signifikan sebesar 0,000 kurang dari 0,05.

3. Lingkungan kerja berpengaruh positif terhadap kinerja pegawai di Dinas Cipta Karya Kabupaten Banyumas. Hal ini ditunjukkan dengan nilai $t_{\text {hitung }}>t_{\text {tabel }}$ yaitu 3,930 > 1,6641 serta nilai signifikan sebesar 0,000 kurang dari 0,05.

4. Pelatihan kerja, pengembangan karir dan lingkungan kerja secara simultan berpengaruh terhadap kinerja pegawai di Dinas Cipta Karya Kabupaten Banyumas. Hal ini ditunjukkan dengan nilai $F_{\text {hitung }}>F_{\text {tabel }}$, yaitu 29,673 > 2,72 serta dengan nilai signifikan sebesar 0,000 kurang dari 0,05 .

\section{Saran}

1. Untuk meningkatkan pelatihan kerja sebaiknya dari awal PNS ditempatkan sesuai pendidikan dan dilakukan pelatihan sesuai bidangnya serta saran untuk diadakan pelatihan sesuai dengan kebutuhan pegawai sehingga pegawai benar-benar memahami tugas dan fungsinya.

2. Untuk meningkatkan pengembangan karir sebaiknya pegawai mengetahui jabatan / posisi yang akan pegawai dapatkan selanjutnya.

3. Untuk meningkatkan lingkungan kerja sebaiknya menyediakan tempat tersendiri untuk menyimpan dokumen agar terlihat lebih rapi.

4. Untuk meningkatkan kinerja sebaiknya ketiga poin diatas terpenuhi maka kinerja pegawai akan meningkat. 


\section{DAFTAR PUSTAKA}

Alghifari. 2000. Analisa Statistik Untuk Bisnis: Regresi, Korelasi dan Nonparametik. BPFE. Yogyakarta.

As’ad, Moh. 2002. Psikologi Industri, Seri Ilmu Sumber Daya Manusia. Liberty: Yogyakarta.

Barthos, Basir. 2004. Manajemen Sumber Daya Manusia Suatu Pendekatan Mikro. Bumi Aksara. Jakarta.

Burlian, Muhammad. 2005. Pengaruh Pengembangan Karir Terhadap Kinerja Pegawai Balai Karantina Ikan Polonia Di Medan. Tesis. Universitas Sumatera Utara.

Desler, Gary. 2006. Manajemen Sumber Daya Manusia. Edisi kesepuluh. PT Indeks. Klaten.

Ghozali, Imam. 2007. Aplikasi Analysis Multi Variate Dengan Program SPSS. BP UNDIP. Semarang.

Gibson, dkk. 1997. Manajemen, EdisiKesembilan.Erlangga: Jakarta.

Gomes, F.C. 1997. Manajemen Sumber Daya Manusia. Andi Offset: Yogyakarta.

Handoko, Hani, 2003, Manajemen Personalia dan Sumber Daya Manusia. BPEE. Yogyakarta.

Hasibuan, Malayu S.P. 2000. Manajemen Sumber Daya Manusia. Bumi Aksara: Jakarta.

Kusriyanto, Bambang. 1991. Meningkatkan Produktivitas Karyawan. PT. Pustaka Binaman Pressindo, Jakarta.

Lewa dan Subowo. 2005. Pengaruh Kepemimpinan, Lingkungan Kerja Fisik Dan Kompensasi Terhadap Kinerja Karyawan Di PT. Pertamina (Persero) Daerah Operasi Hulu Jawa Bagian Barat, Cirebon. Jurnal Sinergi. Hal 129 - 140.

Mangkunegara, Anwar Prabu. 2000. Manajemen Sumber Daya Manusia Perusahaan, Cetakan Kelima. PT. Remaja Rosdakarya: Bandung.

Martoyo, S. 1998. Manajemen Sumber Daya Manusia, Edisi Ketiga. BPFE UGM: Yogyakarta.

Mathis, Robert L. dan Jackson, John H.. 2002. Manajemen sumber daya manusia. Jakarta: Penerbit PT Salemba Emban Patria.

Nitisemito, Alex S. 1996. Manajemen Personalia. Ghaila Indonesia. Jakarta.

Parlinda, Vera dan Wahyuddin, 2004. Pengaruh Kepemimpinan, Motivasi, Pelatihan, Dan Lingkungan Kerja Terhadap Kinerja Karyawan Pada Perusahaan Daerah Air Minum Kota Surakarta.

Penggabean. S. 2002. Manajemen Sumber Daya Manusia. Bogor : Penerbit Ghalia Indonesia.

Prawirosentono, Suyadi. 1999. Kebijakan Kinerja Karyawan ; Kiat Membangun Organisasi Kompetitif Menjelang Perdagangan Bebas Dunia. Yogyakarta : BPFE -Yogyakarta.

Priyatno, Duwi. 2010. Teknik Mudah dan Cepat Melakukan Analisis Data Penelitian dengan SPSS dan Tanya Jawab Ujian Pendadaran. Gava Media. Yogyakarta. 
Robbins, Stepen P. 1996. Prilaku Organisasi. Edisi Indonesia. Jakarta : Penerbit PT Prenhallindo.

Sedarmayanti. 2001. Sumber Daya Manusia dan Produktivitas Kerja. Mandar Maju, Bandung.

Simamora, Henry. 2004, Manajemen Sumber Daya Manusia. Bagian Penerbitan Sekolah Tinggi Ilmu Ekonomi YKPN, Edisi ke-3: Yogyakarta.

Sudjana. 1992. Metode Statistik. Edisi Kelima. Tarsindo: Bandung.

Sugiyono. 2004. Statistik Untuk Penelitian. Cetakan ke 6. CV Alfabeta: Bandung.

Supranto J. 2000. Statistik Teori dan Aplikasi, Erlangga, Jakarta.

Suryana, Dede. 2008. Pengaruh Kepemimpinan Dan Pengembangan Karir Terhadap Motivasi: Kasus Karyawan PT. Indorama Synthetics. Tbk. STIE STAN Indonesia Mandiri.

Umar, Husein. 2002. Riset Pemasaran \& Perilaku Konsumen. Jakarta: Penerbit PT Gramedia Pustaka Utama. 